\title{
THE EFFECT OF PINEAPPLE (Ananas comosus) ON SEX HORMONES OF ADULT MALE RATS
}

Shrouk A. Showky ; Naeem M. Rabeh* and Hany G. EL-Masry

Nutrition and Food Science Department, Faculty of Home Economics, Helwan University, Cairo, Egypt

*E-mail - naeemrabeh@gmail.com

Key Words: Pineapple (Ananas comosus), rats, sex hormones, lipid profile, liver functions

\section{ABSTRACT}

Pineapple (Ananas comosus) has stimulatory effects on sex hormone and semen production as well as sperm motility. The aim of the present study was to investigate the effect of Pineapple (leaves, pulp and husk) supplementation on sex hormones of adult male rats. Thirty adult male albino rats, weighing about $(180 \pm 5 \mathrm{~g})$ were divided randomly into two main groups as follow: the first main group kept as negative control group (6 rats) was fed on basal diet. The second main group ( 24 rats) were fed on basal diet and given orally lead acetate, then divided into 4 subgroups as follow, subgroup 2 (+ve control) fed on basal diet. Groups (3, 4 and 5) were fed on basal diet supplemented with leaves, pulp and husk of dried Pineapple at $10 \%$ each, respectively. At the end of the experimental period (8 weeks), semen was collected from each rat then, rats were scarified to obtain blood then serum was collected for biochemical analyses. Results indicated that Pineapple supplementation either leaves, pulp, or husk significantly $(\mathrm{P}<0.05)$ improved the serum concentrations of (testosterone; FSH), total antioxidant, CAT and significantly decreased MDA, as well as improving liver functions and lipid profile. Moreover, significant improvement in semen analysis were observed as Pineapple supplementation. It could be recommended that incorporating pineapple (leaves, pulp and husk) in a healthy normal diet is essential to boost fertility in adult male rats.

\section{INTRODUCTION}

Infertility is a prevalent condition affecting an estimated 70 million people globally. The World Health Organization estimates that 9\% of couples worldwide struggle with fertility issues and that male factor contributed to $50 \%$ of the issues. Male infertility has different causes, ranging from genetic mutations to lifestyle choices to medical illnesses or medications (Fainberg and Kashanian, 2019).

Pineapple (Ananas comosus) is the third most essential fruit crop in the tropical and subtropical regions of the world, only preceded by banana and citrus. Pineapple is an essential source of sugars, organic acids and some important minerals for human nutrition and its quality of good flavor, aroma, juiciness and sweetness is well known and appreciated by consumers. Moreover, pineapple is also rich in health-promoting 
antioxidants, such as ascorbic acid, flavonoids, and other phenolic compounds related to antioxidant activities (Lu et al., 2014).

Pineapple has stimulatory effects on sex hormone and semen production (Siddiq $\boldsymbol{e t}$ al., 2012) as well as sperm motility. It also exerts protective effects on the semen during the freezing process for storage. The July-August 2009 issue of "Oxidative Medicine and Cellular Longevity" features a study from Indian researchers, which correlates manganese consumption in pineapple juice and other foods with increased sperm movement. It also protected sperm during freezing for storage, which can raise conception chances (Debnath et al., 2012).

One hundred grams of this fruit allows covering about $80 \%$ of the daily demand for vitamin C. Other substances present in the pineapple that are worth mentioning involve folate $(18 \mu \mathrm{g})$ and beta-carotene $(35 \mu \mathrm{g})$ (Zdrojewicz et al., 2018). Pineapple also is a good source of vitamin B1, vitamin B6 (Hossain et al., 2015). It was recorded that vitamin B deficiencies, involving vitamin B6, are linked with gonadal abnormalities in males, such as altered spermatogenesis (Forges et al., 2007and Vujkovic et al., 2009). Throughout the pineapple production and consumption chain, several tons of by-products are produced, which, in most cases, are discarded as waste (Sznida, 2018).

Therefore, this study was conducted to evaluate the effect of dried Pineapple (leaves, pulp and husk) supplementation on sex hormones of adult male rats.

\section{Materials:}

\section{MATERIALS AND METHODS}

Pineapple with its leaves was purchased from local market in Cairo, Egypt. Casein, cellulose, choline bitartrate, D-L methionine, vitamins and minerals were obtained from El-Gomhoriya Pharmaceutical Company. Chemical kits were purchased from Gama Trade Company for Chemical, Cairo, Egypt. Starch, corn oil and sucrose were obtained from the Egyptian local market. Thirty adult male albino rats (Sprague-Dawley

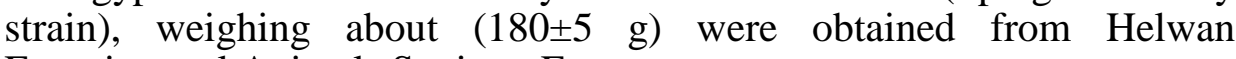
Experimental Animals Station., Egypt.

Methods:

1- Botany of Pineapple (Ananas comosus): Pineapple belongs to the order Bromeliales, Family: Bromeliaceae, Genus: Ananas, Species: A. comosus. This classification was carried out at the Agricultural Research Center, Giza, Egypt.

2. Preparation of Dried Pineapple: Pineapple leaves, pulp, and flesh (husk) were dried by solar energy At the National Research Center, Dokki, Egypt.

3. Induction of impaired fertility: lead acetate was dissolved in $5 \mathrm{ml}$ of distilled water and were administered orally (once daily at 9.00 
am) to male rats at $100 \mathrm{mg} / \mathrm{kg} \mathrm{BW}$ of rats for 4 weeks (Nkechi et al., 2015).

4. Diet Composition and Experimental Animal Design: The basal diet was formulated according to AIN-93M diet (Reeves et al., 1993). Animals (30 rats) were housed in well conditions in biological studies lab of Faculty of Home Economics. They were left for seven days as adaptation period, and they were allowed to feed standard laboratory food and water. After the period of adaptation, animals were divided into 2 main groups, as follows: - the first main group (6 rats) was fed on basal diet and served as a negative control group (-ve), the second main group (24 rats) was fed on basal diet and given orally lead acetate then was divided into 4 subgroups, subgroup 2 (+ve control) fed on basal diet. Groups (3, 4 and 5) were fed on basal diet supplemented with leaves, pulp and husk of dried Pineapple at $10 \%$ each, respectively.

At the end of the experimental period ( 8 weeks), rats were fasted overnight before scarifying and blood samples were collected from each rat and were centrifuged at $3000 \mathrm{rpm}$ for $15 \mathrm{~min}$ to obtain the serum for biochemical analysis.

5. Biological Evaluation: Feed intake (FI), body weight gain percent (BWG\%) and feed efficiency ratio (FER) were determined according to Chapman et al., (1959) using the following equation:

$$
\text { BWG\% = Error! } \times 100
$$

$$
\text { FER = Weight gain } / \text { Feed intake. }
$$

\section{Biochemical Analysis of Serum:}

Follicular stimulating hormone (FSH) and testosterone level were determined according to Loraine and Bell (1976) and Wilke and Utley (1987), respectively. Aspartate aminotransaminase (AST) and Alanine aminotransaminases (ALT) were determined according to the method described by Bergmeyer et al., (1978), and Alkaline phosphates (ALP) was determined according to Belfield and Goldberg (1971). Total antioxidant and Malondialdehyde (MDA) were determined according to Benzie and Strain, (1998) and Placer et al., (1966), respectively. Serum total cholesterol (TC), triglyceride (TG), high density lipoprotein cholesterol (HDL-C) were determined according to Richmond, (1973); Wahlefeld, (1974) and Albers et al., (1983), respectively. Regarding to serum low density lipoprotein cholesterol (LDL-C) and very low-density lipoprotein cholesterol (VLDL-C) were calculated according to Fridewald et al., (1972).

7. Semen Analysis: Semen analysis was determined according to Adamkovicova et al., (2016). 
8. Statistical Analysis: The obtained results were analyzed according to SPSS program (The statistical package for social sciences, version 20.0, Inc., Chicago, Illinois, USA). ANOVA test were used to compare results among groups and $\mathrm{P}<0.05$ was considered to be significant (Snedecor and Cochron, 1989).

\section{RESULTS AND DISCUSSION}

Herbal medicine is commonly used to treat male infertility, and it has been demonstrated in vivo (Kim et al., 2013). It's a good idea to look for any alternative measures that use dietary components with the fewest side effects as a supplement to reduce treatment costs and other unwanted effects. So that, this study was conducted to investigate the effect of dried Pineapple (leaves, pulp and husk) supplementation on sex hormones of adult male rats. Pineapple is high in minerals and vitamins. In addition, pineapple has been shown to have anti-inflammatory and antioxidant properties (Mohd et al., 2020).

Results of Table (1) showed a significant increase in the IBW for all groups as compared to the negative control group. Statistically significant increase $(\mathrm{P}<0.05)$ in the mean value of FBW $(\mathrm{gm})$, for the rats that fed basal diet and supplemented with various derivatives of pineapple, as compare to +ve group. On the other hand, there was statistically significant increase $(\mathrm{P}<0.05)$ in the mean value of $\mathrm{BWG} \%$ as compared to +ve group. As regard to FER, there was statistically significant difference $(\mathrm{P}<0.05)$ in the mean value of FER for the treated rats as compared to +ve control group. Pulp pineapple gave the best improvement in $\mathrm{BWG} \%$ and FER as compared to other derivatives of pineapple.

Table (1): Effect of pineapple leaves, pulp and husk supplementation on body weight status in adult male rats

\begin{tabular}{|c|c|c|c|c|c|}
\hline $\begin{array}{l}\text { Parameters } \\
\text { Groups }\end{array}$ & IBW (g) & FBW $(g)$ & BWG\% & $\underset{(\mathrm{g} / \mathrm{d} / \mathrm{rat})}{\text { FI }}$ & FER \\
\hline Control (-ve) & $172.33 \pm 2.33^{b}$ & $209.3 \pm 2.60^{a}$ & $21.19 \pm 1.45^{a}$ & 15.3 & $0.054 \pm 0.03^{a}$ \\
\hline Control (+ve) & $180.00 \pm 1.73^{a}$ & $186.1 \pm 1.98^{c}$ & $3.41 \pm 1.70^{d}$ & 12.0 & $0.011 \pm 0.05^{d}$ \\
\hline Leaves & $178.00 \pm 1.52^{\mathrm{a}}$ & $198.6 \pm 2.02^{b}$ & $11.62 \pm 1.41^{\mathrm{bc}}$ & 14.5 & $0.032 \pm 0.033^{b c}$ \\
\hline Pulp & $178.83 \pm 1.09^{a}$ & $206.7 \pm 3.52^{\text {ab }}$ & $15.55 \pm 1.59^{b}$ & 15.0 & $0.042 \pm 0.04^{\mathrm{ab}}$ \\
\hline Husk & $181.66 \pm 1.45^{\mathrm{a}}$ & $198.5 \pm 2.18^{b}$ & $9.36 \pm 1.29^{c}$ & 14.2 & $0.027 \pm 0.03^{c}$ \\
\hline
\end{tabular}

Results are expressed as mean \pm SE.

Values in each column which have different letters are significantly different at $(\mathbf{P}<0.05)$.

The current results Table (2) showed statistically significant $(\mathrm{P}<0.05)$ improvement in serum sex hormones of adult male rats (testosterone and FSH) that fed basal diet and supplemented with various derivatives of Pineapple. It was observed that there was no significant difference in serum testosterone between pineapple leaves and pineapple husk, while there was a significant increase $(\mathrm{P}<0.05)$ in the mean value of testosterone for the rats fed pulp pineapple as compared to the 
pineapple leaves or husk group. On other hand, there was a significant difference in the mean of FSH among the treated groups. The best improvement in the concentration of testosterone and FSH was recorded at the group that fed pulp of pineapple.

Table (2): Effect of pineapple leaves, pulp and husk supplementation on serum sex hormones of adult male rats

\begin{tabular}{|c|c|c|}
\hline $\begin{array}{ll}\text { Groups } & \text { Parameters }\end{array}$ & Testosterone (ng/ml) & FSH (ng/ml) \\
\hline Control (-ve) & $2.02 \pm 0.03^{c}$ & $16.43 \pm 0.33^{\mathrm{a}}$ \\
\hline Control (+ve) & $1.38 \pm 0.08^{d}$ & $9.86 \pm 0.22^{d}$ \\
\hline Leaves & $4.40 \pm 0.20^{b}$ & $13.61 \pm 0.32^{b}$ \\
\hline Pulp & $5.08 \pm 0.22^{\mathrm{a}}$ & $17.03 \pm 0.15^{\mathrm{a}}$ \\
\hline Husk & $4.08 \pm 0.20^{b}$ & $11.88 \pm 0.35^{\mathrm{c}}$ \\
\hline
\end{tabular}

Results are expressed as mean $\pm \mathrm{SE}$.

Values in each column which have different letters are significantly different at $(\mathbf{P}<\mathbf{0 . 0 5})$.

Maintaining a sufficient intra-testicular testosterone concentration is critical for testicular function, particularly spermatogenesis (Woolveridge et al., 1998). When comparing the control and treated groups in Leko et al., (2021) study, there was a statistically significant difference in testosterone hormone levels; the rats that received aluminium chloride and a high dose of pineapple juices had the highest value and the negative control group that received aluminium alone had the lowest. Pineapple juices boosted testosterone in a dose-dependent way, implying that they improved male fertility. One cup of pineapple juice contains $1.3 \mathrm{mg}$ of manganese (Debnath et al., 2012), which is enough to meet up to 73 percent of daily needs (Hossain et al., 2015). At 55 days of age, the rats given the $25 \mathrm{mg} / \mathrm{kg}$ dose had higher levels of LH, $\mathrm{FSH}$, and testosterone. Furthermore, there was a concurrent rise in both daily sperm production and spermatogenesis efficiency $(\mathrm{P}<0.05)$, indicating a Mn-induced spermatogenesis acceleration (Lee et al., 2006).

Results of Table (3) showed statistically significant increase $(\mathrm{P}<0.05)$ in antioxidant status regarding total antioxidant and CAT and a significant decrease $(\mathrm{P}<0.05)$ in MDA in adult male rats that fed with various derivatives of Pineapple. As regard T. Antioxidant, CAT, MDA there was statistically significant difference $(\mathrm{P}<0.05)$ for the rats that fed with various derivatives of pineapple. The most improvement of antioxidant status was observed at the rats fed on pulp pineapple as compared to the treatments.

Because large amounts of reactive oxygen species and poor antioxidant status have been linked to infertility, treatment focused on ways to improve the reproductive microenvironment's exhausted antioxidant defense is logical (Adeoye et al., 2018). 
Table (3): Effect of Pineapple Leaves, Pulp and Husk on T. antioxidant, CAT and MDA in Adult Male Rats

\begin{tabular}{|c|c|c|c|}
\hline Groups $\quad$ Parameters & $\begin{array}{l}\text { T. Antioxidant (n } \\
\mathrm{mol} / \mathrm{ml})\end{array}$ & CAT ( & $\operatorname{MDA}(\mathbf{n m o l} / \mathrm{ml})$ \\
\hline Control (-ve) & $1.02 \pm 0.03^{\mathrm{c}}$ & $130.96 \pm 2.21^{\mathrm{a}}$ & $2.92 \pm 0.04^{d}$ \\
\hline Control (+ve) & $0.57 \pm 0.05^{d}$ & $76.43 \pm 3.03^{\mathrm{d}}$ & $6.33 \pm 0.38^{\mathrm{a}}$ \\
\hline Leaves & $1.65 \pm 0.05^{b}$ & $107.50 \pm 1.09^{b}$ & $3.93 \pm 0.12^{\mathrm{c}}$ \\
\hline Pulp & $2.04 \pm 0.10^{\mathrm{a}}$ & $123.33 \pm 3.33^{\mathrm{a}}$ & $3.16 \pm 0.13^{d}$ \\
\hline Husk & $1.03 \pm 0.08^{c}$ & $91.16 \pm 3.76^{c}$ & $4.75 \pm 0.20^{b}$ \\
\hline
\end{tabular}

Results are expressed as mean $\pm \mathrm{SE}$.

Values in each column which have different letters are significantly different at $(\mathbf{P}<0.05)$.

The MDA level was reduced by $60.16 \%$ after treatment with pineapple peel extract at $2.5 \mathrm{~mL} / \mathrm{kg}$ bw. This was found to be more efficacious than a double-dose treatment $(5.0 \mathrm{~mL} / \mathrm{kg} \mathrm{bw})$. Treatment with $2.5 \mathrm{~mL} / \mathrm{kg}$ bw pineapple peel extract increased catalase activity by 87.46 $\%$, but treatment with a twofold dose $(5.0 \mathrm{~mL} / \mathrm{kg}$ bw $)$ lowered activity by $32.67 \%$ (Okafor et al., 2011). Pineapple manganese content also is a cofactor for several enzymes involved in energy synthesis and antioxidant activities (Siddiq et al., 2012).

Bromelain found in the pineapple, is a proteolytic enzyme that can act as an antioxidant (Saptarini et al., 2019). Effects of bromelain on oxidative stress indicators in dichlorvos-intoxicated mice's serum were studied by Agarwal et al., (2016).

Results of Table (4) showed statistically significant improvement in liver function parameters regarding ALT, AST and ALP levels in adult male rats that fed with various derivatives of Pineapple as compared to + ve control group.

It was clear that, there was no significant difference in serum AST, ALT and ALP between the groups fed either dried pineapple leaves or pulp. Also, no changes in the mean of AST and ALT between the groups fed either dried leaves or pulp of pineapple. pineapple Pulp gave the most improvement of liver functions.

Aminotransferase readings can be used to assess seminal quality, with the AST/ALT ratio being used to differentiate between different kinds of azoospermia according to (Buitrago et al., (1981). A considerable reduction in AST (99.8\%) and ALP (56.53\%) levels was seen after treatment with pineapple peel extract at $2.5 \mathrm{~mL} / \mathrm{kg}$ bw. While; Treatment with $2.5 \mathrm{~mL} / \mathrm{kg}$ bw pineapple peel extract resulted in a rise in ALT levels. However, a double dose $(5.0 \mathrm{~mL} / \mathrm{kg}$ bw) resulted in a 10.06 $\%$ reduction (Okafor et al., 2011). 
Table (4): Effect of pineapple leaves, pulp and husk supplementation on liver functions in adult male rats

\begin{tabular}{|c|c|c|c|}
\hline \multirow{2}{*}{$\begin{array}{ll}\text { Groups } & \text { Parameters } \\
\end{array}$} & AST & ALT & ALP \\
\hline & \multicolumn{3}{|c|}{$(\mu / L)$} \\
\hline Control (-ve) & $64.82 \pm 3.24^{d}$ & $26.53 \pm 0.64^{c}$ & $79.90 \pm 4.93^{c}$ \\
\hline Control (+ve) & $93.46 \pm 1.99^{a}$ & $37.83 \pm 0.99^{a}$ & $104.33 \pm 1.65^{\mathrm{a}}$ \\
\hline Leaves & $80.07 \pm 1.15^{\text {bc }}$ & $31.96 \pm 0.96^{b}$ & $83.13 \pm 1.60^{c}$ \\
\hline Pulp & $74.53 \pm 1.81^{\mathrm{c}}$ & $28.36 \pm 0.84^{\mathrm{c}}$ & $80.63 \pm 3.67^{\mathrm{c}}$ \\
\hline Husk & $84.62 \pm 2.47^{b}$ & $34.40 \pm 0.55^{b}$ & $93.47 \pm 1.84^{b}$ \\
\hline
\end{tabular}

Results are expressed as mean \pm SE.

Values in each column which have different letters are significantly different at $(\mathbf{P}<0.05)$.

A significant improvement $(\mathrm{P}<0.05)$ in lipid profile as shown in Table (5) in adult male rats that fed basal diet supplemented with various derivatives of Pineapple by reducing the mean value of TC, TG, LDL-C and increasing the level of HDL-C as compared to +ve group. Moreover, there was a significant difference $(\mathrm{P}<0.05)$ among the three treated groups for lipid profile. The lowest value TG, LDL-C and VLDL-C and the highest value of HDL-C; were found in Group that fed on Pineapple Pulp followed by Pineapple husk,

Many animal studies have shown that hypercholesterolemia, steroidogenesis, and male fertility are linked (Xu et al., 2007 and Whitfield et al., 2015). Serum VLDL, total triglyceride, and testosterone levels were all found to be strongly linked to sperm motility (Ergün $\boldsymbol{e t}$ al., 2007).

Table (5): Effect of pineapple leaves, pulp and husk supplementation on lipid profile of adult male rats

\begin{tabular}{|c|c|c|c|c|c|}
\hline \multirow{2}{*}{$\begin{array}{l}\text { Parameters } \\
\text { Groups }\end{array}$} & TC & TG & VLDL-C & HDL-C & LDL-C \\
\hline & \multicolumn{5}{|c|}{ (mg/dl) } \\
\hline Control (-ve) & $73.88 \pm 3.17^{\mathrm{c}}$ & $50.53 \pm 0.74^{e}$ & $10.10 \pm 0.14 \mathrm{e}$ & $48.00 \pm 1.61^{a}$ & $15.77 \pm 4.31^{\mathrm{de}}$ \\
\hline Control (+ve) & $92.70 \pm 1.68^{a}$ & $75.04 \pm 2.14^{a}$ & $15.00 \pm 0.42^{a}$ & $23.30 \pm 0.52^{d}$ & $54.39 \pm 1.72^{a}$ \\
\hline Leaves & $71.06 \pm 0.63^{\mathrm{cb}}$ & $63.56 \pm 2.10^{c}$ & $12.71 \pm 0.42^{\mathrm{c}}$ & $37.63 \pm 1.28^{b}$ & $20.72 \pm 0.86^{c}$ \\
\hline Pulp & $65.96 \pm 0.92^{\mathrm{d}}$ & $57.46 \pm 1.16^{d}$ & $11.49 \pm 0.23^{\mathrm{d}}$ & $44.86 \pm 1.48^{a}$ & $9.60 \pm 2.22^{\mathrm{d}}$ \\
\hline Husk & $81.06 \pm 1.59^{b}$ & $69.53 \pm 0.75^{b}$ & $13.09 \pm 0.15^{b}$ & $32.43 \pm 1.14^{\mathrm{c}}$ & $34.72 \pm 1.51^{b}$ \\
\hline
\end{tabular}

Results are expressed as mean $\pm \mathrm{SE}$.

Values in each column which have different letters are significantly different at $(\mathbf{P}<\mathbf{0 . 0 5})$.

Gallic acid, gentisic acid, syringic acid, vanillin, ferulic acid, sinapic acid, isoferulic acid, and o-coumaric acid are among the eight phenolic chemicals found in pineapple fruits (Yapo et al., 2011). In obese mice, gallic acid lowered body weight and serum triacylglycerol (McGarry and Brown, 1997). Pineapple has a high fat binding capacity (FBC), which is significant for detecting anti-obesity properties in diet. Bromelain has been shown to be beneficial in the treatment of stoutness 
in a few clinical studies (Mohamed et al., 2014). When compared to the obese group, pineapple extract was found to enhance HDL levels, indicating that pineapple may be able to reduce the risk of lipid-related disorders (Emmanuel et al., 2016). The reduction in blood cholesterol in the pineapple juice groups in the study of El-Shazly et al., (2018) was accompanied by a reduction in the LDL percentage. As a result, it lowers the atherogenic index, presumably through improving LDL catabolism via hepatic receptors (Xie et al., 2005).

Regarding to Semen analysis, Results of Table (6) showed statistically significant $(\mathrm{P}<0.05)$ improvement in semen analysis (normal count as well as abnormal count) in adult male rats that fed with various derivatives of Pineapple as compared to +ve control group. There was no significant difference in the mean value of normal and abnormal semen analysis, for the rats that fed either dried pineapple leaves or husk. The highest normal semen count was observed at the group fed on pineapple pulp as compared to the other treatments

Table (6): Effect of pineapple leaves, pulp and husk supplementation on semen of adult male rats

\begin{tabular}{|c|c|c|}
\hline $\begin{array}{ll}\text { Groups } & \text { Parameters } \\
\end{array}$ & Normal (\%) & Abnormal (\%) \\
\hline Control (-ve) & $87.62 \pm 4.01^{\mathrm{a}}$ & $12.38 \pm 4.01^{\mathrm{d}}$ \\
\hline Control (+ve) & $53.10 \pm 2.46^{d}$ & $46.90 \pm 2.46^{\mathrm{a}}$ \\
\hline Leaves & $65.73 \pm 1.46^{c}$ & $34.26 \pm 1.46^{b}$ \\
\hline Pulp & $75.93 \pm 2.70^{b}$ & $24.06 \pm 2.70^{c}$ \\
\hline Husk & $63.99 \pm 2.02^{c}$ & $36.01 \pm 2.02^{b}$ \\
\hline
\end{tabular}

Results are expressed as mean $\pm \mathrm{SE}$.

Values in each column which have different letters are significantly different at $(\mathbf{P}<\mathbf{0 . 0 5})$.

Because of its stimulatory effects on sex hormone and semen production (Siddiq et al., 2012), as well as sperm motility, pineapple juice may be utilized to promote fertility by improving semen quality (Hossain et al., 2015). It also protects the sperm throughout the freezing process so that it may be stored (Debnath et al., 2012). In agreement with these results recently, Leko et al., (2021) found that the rats fed with pineapple juice had significantly higher concentration counts, motile counts, progressive assessments, and morphology, indicating good spermatogenesis and testicular steroidogenesis.

One hundred gram of fresh pineapple ripe contains $11 \mathrm{mcg}$ of folic acid and $5 \mathrm{mcg}$ of folic acid present in syrup. One ripe pineapple fruit can supply about $16.2 \%$ of daily requirement for vitamin $\mathrm{C}$ in an adult. Furthermore, half a glass of pineapple juice provides up to $28 \mathrm{mg}$ of vitamin C (Debnath et al., 2012). Pineapple also is a good source of vitamin B1, vitamin B6 (Hossain et al., 2015). Because they both operate together in the process of DNA creation and the creation of S-adenosyl methionine, vitamin B and folate are effective markers of male fertility 
(Froese et al., 2019). Vitamin C supplementation in infertile men improved sperm count, motility, and morphology, suggesting that it could be used as a supplement to increase sperm quality in the lead up to conception according to Akmal et al., (2006).

From the above-mentioned results it could be conducted that, Pineapple (Ananas comosus) supplementations have raising sex hormones productions also shown possible capacity to positively influence male fertility directly and indirectly by affecting lipid profile lowering cholesterol, triglycerides, LDL while raising HDL beside enhancing antioxidant effects against free radicals through beneficial effects of its contents of bromelain and other vitamins and minerals.

To boost fertility in adult male rats, incorporate pineapple derivatives in a healthy normal diet as a rich source of antioxidant compounds. People with infertility should have to eat pineapple; pineapple is a wonderful fertility super food because it is inexpensive and readily available in most shops.

\section{REFERENCES}

Adamkovicova, M. ; R. Toman and M. Martiniakova (2016): Sperm motility and morphology changes in rats exposed to cadmium and diazinon. Reprod Biol Endocrinol.,14(42):1-7.

Adeoye, O. ; J. Olawumi ; A. Opeyemi and O. Christiania (2018): Review on the role of glutathione on oxidative stress and infertility. JBRA Assisted Reproduction, 22(1):61-66.

Agarwal, S. ; B. Chaudhary and R.Bist (2016): Bacoside A and bromelain relieve dichlorvos induced changes in oxidative responses in mice serum. Chem Biol Interact.; 254:173-8.

Akmal, M. ; J. Q Qadri ; N. S. Al-Waili ; S. Thangal ; A. Haq and K.Y. Saloom (2006): Improvement in human semen quality after oral supplementation of vitamin C. Journal of Medicinal Food, 9(3):440-442.

Albers, N. ; V. Benderson and G. Warnick (1983): Enzaymatic determination of high density lipoprotein cholesterol, Selected Methods. Clin. Chem., 10: 91-99.

Belfield, A. and D. Goldberg (1971): Revised assay for serum phenyl phosphatase activity using 4- amino-antipyrine. Enzyme, 12(5):561-573.

Benzie, I. and J. Strain (1998): Ferric reducing/antioxidant power assay: direct measure of total antioxidant activity of biological fluids and modified version for simultaneous measurement of total antioxidant power and ascorbic acid concentration. Methods in Enzymology, 299:15-27. 
Bergmeyer, H. ; P. Schreiber and A. Wahlefeld (1978): Optimization of methods for aspartate and alanine aminotransferase. Clinical Chemistry, 24: 58-61.

Buitrago, J.M. ; L.C. Diez and E. Battaner (1981): Human semen aspartate aminotransferase and alanine aminotransferase activity in male fertility studies. Andrologia, 13(4):335-341.

Chapman, D. ; R. Gastilla and J. Campbell (1959): Evaluation of protein in foods: 1- AMethod for the determination of protein efficiency ratio. Can. J. Biochem. Phys., 37: 679-686.

Debnath, P. ; P. Dey and A. Chanda (2012):A Survey on Pineapple and its medicinal value. Scholars Academic Journal of Pharmacy., 1: 24-29.

El-Shazly, S.A. ; M.M. Ahmed ; M.S. Al-Harbi ; M.E. Alkafafy ; H.B. El-Sawy and S. Amer (2018): Physiological and molecular study on the anti-obesity effects of pineapple (Ananas comosus) juice in male Wistar rat. Food science and biotechnology, 27(5):1429-1438.

Emmanuel, E.U. ; E.S. Onagbonfeoana ; O.C. Adanma ; O.C. Precious ; A.I. Faith and O.Y. Ndukaku, (2016): In vivo, in vitro antioxidant and hypolipidemic activity of methanol extract of pineapple peels in Wistar Rats. Int. J. Biosci; 8(6):64-72.

Ergün, A. ; S.K. Köse ; K. Aydos ; A. Ata and A. Avci (2007). Correlation of seminal parameters with serum lipid profile and sex hormones. Archives of Andrology, 53(1):21-23.

Fainberg, J., and J.A. Kashanian (2019). Recent advances in understanding and managing male infertility. F1000Research, 8, F1000 Faculty Rev-670.

Forges, T. ; P. Monnier-Barbarino ; J.M. Alberto ; R.M. GueantRodriguez ; J.L. Daval and J.L. Gueant (2007): Impact of folate and homocysteine metabolism on human reproductive health. Hum Reprod Update.; 13:225-38.

Fridewald, W. ; R. Leve and D. Fredrickson (1972): Estimation of theconcentration of low densitylipoprotein separated by three different methods. Clin.Chem., 18: 499-502.

Froese, D.S. ; B. Fowler and M. R. Baumgartner (2019). Vitamin B12, folate, and the methionine remethylation cycle-biochemistry, pathways, and regulation. Journal of inherited metabolic disease, 42(4):673-685. 
Hossain, M.F. ; S. Akhtar and M. Anwar (2015): Nutritional value and medicinal benefits of pineapple. International Journal of Nutrition and Food Sciences; 4: 84-88.

Kim, S.I. ; Y.S. Jang ; S.H. Han ; M.J. Choi ; E.H. Go ; Y.P. Cheon ; J.S. Lee and S.H. Lee (2012). Effect of manganese exposure on the reproductive organs in immature female rats. Development and Reproduction, 16(4):295-300.

Lee, B. ; M. Pine ; L. Johnson ; V. Rettori ; J.K. Hiney and W.L. Dees (2006). Manganese acts centrally to activate reproductive hormone secretion and pubertal development in male rats. Reproductive toxicology (Elmsford, N.Y.), 22(4):580-585.

Leko, B.J. ; S.T. Olawuyi and L.U. Okon (2021). The mitigating effect of Ananas comosus on aluminum-induced oxidative stress on the testes of adult male Wistar rats. JOBAZ, 82:12.

Loraine, J. and E. Bell (1976): Hormone Assays and their Clinical Application. The 2 Edition., Churchill Livingstone., New York., 221.

Lu, X. ; D. Sun ; Q. Wu ; S. Liu and G. Sun (2014): Physico-chemical properties, antioxidant activity and mineral contents of pineapple genotypes grown in china. Molecules. 19(6):8518-8532.

McGarry, J.D. and N.F. Brown (1997): The mitochondrial carnitine palmitoyltransferase system. From concept to molecular analysis. European Journal of Biochemistry, 244(1):1-14.

Mohamed, G.A. ; S.R.M. Ibrahim ; E.S. Elkhayat and R. Salah EI Dine (2014): Natural anti-obesity agents. Bul. Fac. Pharm. Cairo Univ., 52(2):269-284.

Mohd Ali, M. ; N. Hashim ; S. Abd Aziz and O. Lasekan (2020). Pineapple (Ananas comosus): A comprehensive review of nutritional values, volatile compounds, health benefits, and potential food products. Food research international (Ottawa, Ont.), 137:109675.

Nkechi, E.; I. Bright and O. Rose (2015): The Effect of Lead Acetate on the Testes of Male Albino Rats. Advances in Life Science and Technology, 38: 70-74.

Okafor, O.Y. ; O.L. Erukainure ; J.A. Ajiboye ; R.O. Adejobi ; F.O. Owolabi and S.B. Kosoko (2011): Modulatory effect of pineapple peel extract on lipid peroxidation, catalase activity and hepatic biomarker levels in blood plasma of alcohol-induced oxidative stressed rats. Asian Pacific Journal of Tropical Biomedicine, 1(1): $12-14$. 
Placer, Z.; L. Cushman and B. Johnson (1966): Estimation of product of lipid peroxidation (malonyl dialdehyde) in biochemical systems. Analytical Biochemistry, 16(2):359-364.

Reeves, P. ; F. Nielsen and G. Fahmy (1993): AIN-93. Purified diets forlaboratory rodents: Final reports of the American Institute of Nutrition adhoewriling committee of reformulation of the AIN-76 A Rodent Diet. J. Nutr., 123:1939-1951.

Richmond, N. (1973): Colorimetric determination of total cholesterol and high density lipoprotein cholesterol (HDL-c). Clin. Chem., 19: 1350- 1356.

Saptarini, N.M. ; D. Rahayu and I.E. Herawati (2019): Antioxidant Activity of Crude Bromelain of Pineapple (Ananas comosus (L.) Merr) Crown from Subang District, Indonesia. J Pharm Bioallied Sci.; 11(Suppl 4):S551-S555.

Siddiq, M. ; J. Ahmed and M. Lobo (2012): Tropical and Subtropical Fruits: Postharvest Physiology, Processing and Packaging. John Wiley and Sons, Ames.

Snedecor, G.W. and W.G. Cochron (1989) Statistical methods. 8th edi, USA, Lowa. State Univ. Press, Ames, Lowa.

Sznida, E. (2018): The EU's Path Toward Sustainable Development Goals - Responsible Consumption and Production. SSRN.

Vujkovic, M. ; J.H. de Vries ; G.R. Dohle ; G.J. Bonsel ; J. Lindemans and et al. (2009): Associations between dietary patterns and semen quality in men undergoing IVF/ ICSI treatment. Hum Reprod.; 24: 1304-12.

Wahlefeld, A. (1974): Methods of Enzymatic Analysis. Academic Press, Chapter., 5: 1831-1835.

Whitfield, M. ; X. Pollet-Villard ; R. Levy ; J.R. Drevet and F. Saez (2015):Posttesticular sperm maturation, infertility, and hypercholesterolemia. Asian Journal of Andrology, 17(5):742-748.

Wilke, T. and D. Utley (1987): Total testosterone, free androgenic index and calculated free testosterone by analog RIA method. Clinical Chemistry, 33: 1372-1375.

Woolveridge, I. ; A.A. Bryden ; M.F. Taylor ; N.J. George ; F.C. Wu and I.D. Morris (1998): Apoptosis and expression of apoptotic regulators in the human testis following short- and long-term anti-androgen treatment. Molecular Human Reproduction, 4(7):701-707. 
Xie, W. ; D. Xing ; H. Sun ; W. Wang ; Y. Ding and L. Du (2005): The effects of Ananas comosus L. leaves on diabetic-dyslipidemic rats induced by alloxan and a high-fat/high-cholesterol diet. The American Journal of Chinese Medicine, 33(1):95-105.

Xu, Q. ; H.Y. Lin ; S.D. Yeh ; I.C. Yu ; R.S. Wang ; Y.T. Chen ; C. Zhang ; S. Altuwaijri ; L.M. Chen ; K.H. Chuang ; H.S. Chiang ; S. Yeh and C. Chang (2007): Infertility with defective spermatogenesis and steroidogenesis in male mice lacking androgen receptor in Leydig cells. Endocrine, 32(1):, 96-106.

Yapo, E.S. ; H.T. Kouakou ; L.K. Kouakou ; J.Y. Kouadio ; P. Kouamé and J.M. Mérillon (2011): Phenolic profiles of pineapple fruits (Ananas comosus L. Merrill). Influence of the origin of suckers. Aust. J. Basic Appl. Sci; 5(6):1372-1378.

Zdrojewicz, Z. ; J. Chorbińska ; B. Bieżyński and P. Krajewski (2018): Health-promoting properties of pineapple. Pediatr Med Rodz., 14 (2):133-142.

\section{تأثير الأناناس على الهرمونات الجنسية لذكور الفئران البالغة}

$$
\text { شروق أحمد شوقي ، نعيم محمد لابح ، هاني جابر المصري }
$$

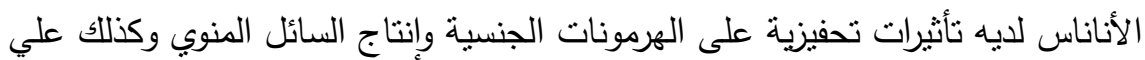

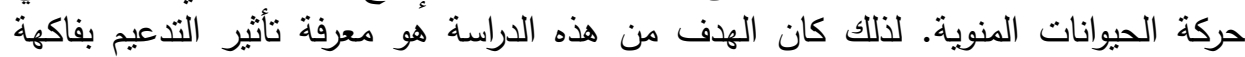

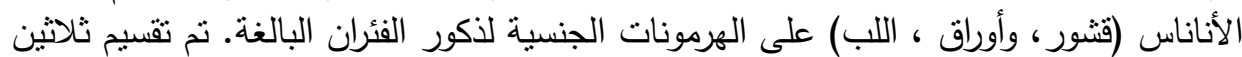

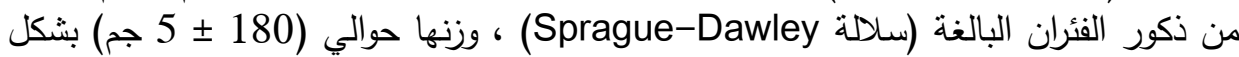

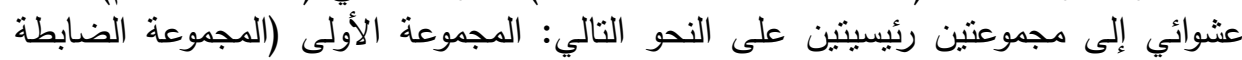

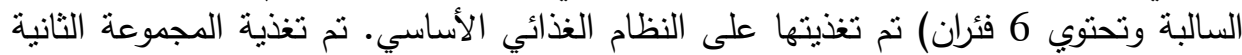

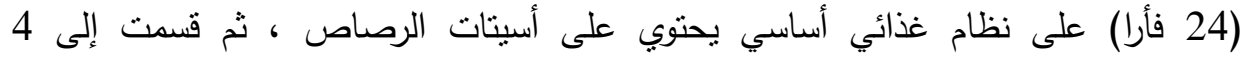

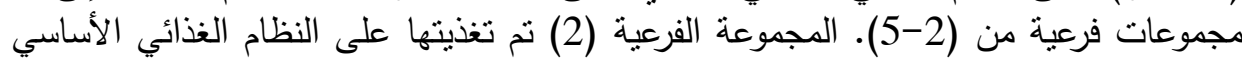

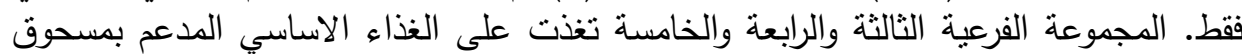

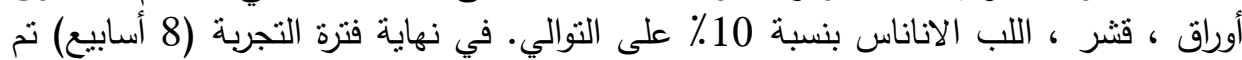

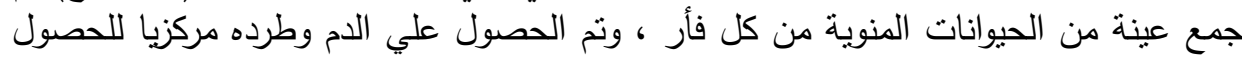
علي السيرم لاستخدامه في التحاليل البيوكيميائية.

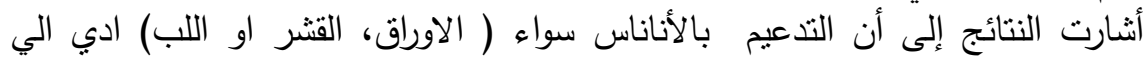

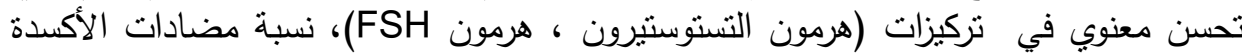

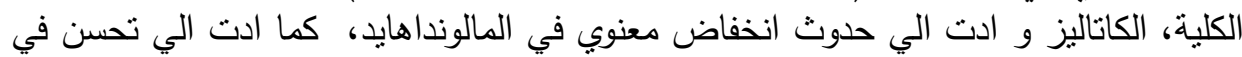

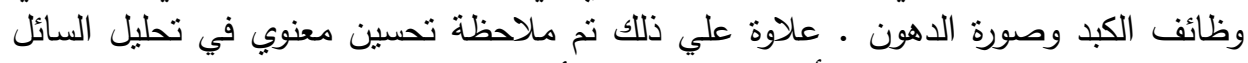

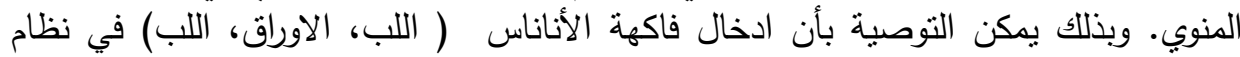
غذائي صحي طبيعي ضروري لزيادة الخصوبة لدى ذكور الفئران البالغة. 